\title{
Countering Criticism from the Third World: Switzerland's Stance on White Minority Rule
}

In the late 1960 s and early 1970s, the Swiss government's position towards Portuguese colonialism and the independence wars in Angola, Mozambique, and Guinea-Bissau was not fundamentally different from during the early years of the conflict. The Swiss authorities still preferred to avoid taking a stand and tried to keep the door open to both the coloniser and the colonised. This was increasingly difficult, however, as Portugal became the last European colonial power to resist decolonisation. For the authoritarian Estado Novo regime led by António de Oliveira Salazar, the colonies of Angola, Mozambique, Guinea-Bissau, Cape Verde, and São Tomé e Príncipe were an integral part of the Portuguese empire. Since the early 196os, the Portuguese authorities had been involved in costly counter-insurgency wars against African liberation movements fighting for independence. ${ }^{1}$ Initial hopes for change after Marcello Caetano took over from a hospitalised Salazar in September 1968 were soon dashed. ${ }^{2}$ As Portuguese colonialism became an anachronism, it was subsumed under the general problem of systematic racial discrimination in Southern Africa. Together with the white settler regime in Rhodesia that had, in 1965, unilaterally declared its independence from the UK, and an Apartheid South Africa that occupied Namibia, the Portuguese colonies formed part of a bastion of white minority rule in Southern Africa. The three minority regimes cooperated militarily to combat the challenge of African nationalism, notably negotiating a secret, informal military agreement called Exercise Alcora in the latter half of 1970. Although Pretoria provided some military support to Lisbon and Salisbury, each government was critical of the others' different, but always discriminatory, way of organising their multiracial societies. ${ }^{3}$

1 MacQueen, The Decolonization of Portuguese Africa.

2 Lopes, West Germany and the Portuguese Military Dictatorship, p. 7.

3 See Miller, An African Volk, pp. 95-10o; Paulo Correia, Grietjie Verhoef, "Portugal and South Africa: Close Allies or Unwilling Partners in Southern Africa during the Cold War?" Scientia Militaria: South African Journal of Military Studies 37:1 (2009), pp. 50-72; Filipe Ribeiro de Meneses, Robert McNamara, "The Origins of Exercise ALCORA, 1960-71", The International History Review 35:5 (2013), pp. 1113-1134; Filipe Ribeiro de Meneses, Robert McNamara, "Exercise ALCORA: Expansion and Demise, 1971-4", The International History Review 36:1 (2014), pp. 89-111. 
In international settings, the white minority regimes in Southern Africa were frequently discussed as a single issue. This was problematic for Switzerland's foreign policy during the late independence wars in the Portuguese colonies. Switzerland was not a former colonial power like the UK and France, did not cooperate militarily with the Estado Novo regime like the Nixon administration, France, and the FRG, and its economic relations with Portugal and its colonies remained limited. Nevertheless, its prominent economic position in South Africa and its government's independent stance on the UN sanctions against Rhodesia ensured it considerable negative attention from Third World governments. Fearing that its political and economic relations with these states might otherwise suffer, the Swiss government felt compelled to react to their challenges.

Up until the Carnation Revolution in April 1974, the Swiss government never publicly took a stand against Portugal's colonial rule or the manner in which the Estado Novo regime oppressed the African liberation movements. Its distanced attitude towards Portuguese colonialism was reinforced by a legalistic view of decolonisation. "Legally, Portugal's sovereignty over the territories in question, which has been established for centuries, is hardly disputable", argued Ambassador Ernesto Thalmann of the DIO in April 1968. ${ }^{4}$ Thus, Bern refused to discuss the issue of colonialism in moral terms and considered decolonisation an internal affair of the Portuguese regime. At the same time, there was widespread awareness that the movement towards decolonisation was inevitable and that something had to be done to show Switzerland's interest in the colonies' African populations in order to facilitate the future establishment of political relations with independent states.

The Swiss government's position during the independence wars in Portuguese Africa was determined on a case-by-case basis and influenced by its selective understanding of neutrality, which was characterised by the emphasis on non-interference, as well as by its political and economic interests. Fierce debates about colonialism and white minority rule at the UN and other international organisations meant that the Swiss government could no longer rely solely on its position of neutrality and abstention to protect itself from criticism. In order to improve Switzerland's image and dispel the impression of being allied to the colonial power, Swiss foreign policymakers made use of two policy instruments that allowed them to make a positive contribution: granting humanitarian and development aid to the African populations and proposing its good offices to the belligerents.

4 Ernesto Thalmann, head of the Dio, "Instructions aux délégations suisses dans les conférences internationales au sujet de l'admission et de l'exclusion de certains pays", 10.04.1968, pp. 4-5, dodis.ch/33555. 
The granting of aid was in accordance with the principle of solidarity that had been part of Switzerland's conception of neutrality since the Second World War. However, Swiss government aid to the Portuguese colonies was small-scale. In 1967, the STC began to financially support the humanitarian work of Swiss missions in Angola, Mozambique, and South Africa, despite the fact that the latter was not considered a developing country and that the STC did not usually grant aid to dependent territories. This change in policy was justified, inter alia, with the argument that the people living in these countries should not be punished for the omissions of their governments. ${ }^{5}$ Until the end of 1969, the STC granted a total of CHF 400,000 to support the deployment of volunteers to Swiss missions that worked in the fields of education, medicine, and religion in Mozambique (22 people) and Angola (6 people). ${ }^{6}$ In 1969, the Federal Government also collaborated with the Swiss Mission in Mozambique on a donation of 10 tons of powdered milk that was distributed in the country by missionaries. ${ }^{7}$ Nevertheless, compared to the contributions to Rwanda and India - the main beneficiaries of Swiss aid that had received more than CHF 18 million each by the end of $1968^{8}$ — Switzerland's bilateral aid to the Portuguese colonies was negligible and could not be counted upon to foster much political goodwill.

The instrument of granting scholarships to shape the future cadres of independent states looked promising, but was not handled flexibly enough to produce the desired outcome. Swiss foreign policymakers hoped that the beneficiaries of scholarships to study in Switzerland would later be well disposed towards the country. In their view, admitting such students also protected the beneficiaries from Communist influence. ${ }^{9}$ However, scholarships in Switzerland are granted on an intergovernmental basis; African students' applications had to go through the Portuguese bureaucracy, which preferred to reserve the scholarships for metropolitan students. In mid-1972, the DPA and the DIO

5 Note from Sigismond Marcuard, Delegate for Technical Cooperation, to the DIO, 26.02.1968, p. 2, SFA E2OO3A\#1980/85\#1971*.

6 Note from Richard Pestalozzi, deputy head of the STC, to Ernst Henri Léchot, responsible for relations with Portugal within the Trade Division, "Technische Zusammenarbeit mit Portugal", 29.12.1969, SFA E2005A\#1980/82\#707*.

7 Report from Jean-Pierre Bertrand, Swiss consul in Mozambique, to the FPD, "Geschäftsbericht des schweizerischen Konsulats in Lourenço Marques 1969", 29.01.1971, p. 13, SFA E2400\#1991/232\#22*.

8 Theodor Kunz, sTC, memorandum, "Liste der Entwicklungsländer, für welche die Schweiz Verpflichtungen eingegangen ist (inkl. Auszahlungen per 31.12.1968)", 15.01.1969, p. 1, dodis. $\mathrm{ch} / 32947$.

9 Trachsler argues that from its inception, Switzerland's development aid programme had strongly anti-Communist intentions and was aimed at containing Communist influence in the Third World: Trachsler, "Neutralität, Solidarität und Kalter Krieg". 
considered it inappropriate to interfere in Portugal's choice and to reserve one of the two scholarships offered to Portugal for a student of African origin. The two services feared a negative reaction from Lisbon. ${ }^{10}$

For African nationalists, obtaining scholarships and other forms of humanitarian aid was about more than material support for their struggle. In September 1972, Pedro Gadimpovi, responsible for national education in the Angolan Revolutionary Government in Exile (GRAE), contacted the STC. He wished to open "a channel of cooperation between your organisation and my department" and asked the STC to create opportunities for young Angolans to study in Switzerland. ${ }^{11}$ The wording of his request underlines the GRAE's aspiration to establish itself as a legitimate counterpart of the Swiss authorities-and the true representative of the Angolan people. The STC, however, insisted that Swiss scholarships were only attributed to governments, thereby thwarting the GRAE's attempt at gaining international recognition. ${ }^{12}$ FPD officials' unwillingness to risk offending Portugal by giving the impression of politically supporting African nationalists undermined the fiction of non-political aid. It also limited the effectiveness of this policy instrument to improve the image of Switzerland's neutrality and to create good preconditions for the Portuguese colonies' independence.

The principle of availability, which underlines Switzerland's willingness to offer mediation and good offices during armed conflicts, has been part of the country's conception of neutrality since the early $1960{ }^{13}{ }^{13}$ Yet, by the end of the decade, Switzerland's neutrality was no longer seen as a sufficient guarantee for its impartiality, as Albert Natural of the DPA stated at the annual conference of Swiss ambassadors in 1967: "In the second half of the 2oth century, conflicts usually take place between states of different ideologies or races. Consequently, the fact that Switzerland is liberal and white can cause [...] totalitarian regimes and coloured peoples to distrust us." Natural underlined that African actors in particular preferred to look for regional mediators. ${ }^{14}$ Indeed, there were few opportunities for Switzerland's good offices during the independence wars in Portuguese Africa. The Estado Novo regime had little interest in negotiations

10 Note from Jean-Jacques Indermühle, DPA, to the DIO, "Bourses fédérales pour le Portugal”, 14.07.1972, SFA E2OO1E-o1\#1982/58\#6126*; see also note from FR, DIO, to Lukas Burckhardt, DIO, "Stipendiengesuche von Angehörigen portugiesischer Provinzen", 11.07.1972, attached to the note from Lukas Burckhardt to the DPA, "Bundesstipendien für Portugal", 12.07.1972, SFA E2OO1E-o1\#1982/58\#6126*.

11 Letter from Pedro Gadimpovi, GRAE, to the STC, 04.09.1972, SFA E2OO5A\#1983/18\#183*.

12 Letter from Benoît Frochaux, STC, to the GRAE, 19.09.1972, SFA E2OO5A\#1983/18\#183.

13 Möckli, Neutralität, Solidarität, Sonderfall, p. 28o.

14 Albert Natural, DPA, draft speech, "Note en vue de la conférence des Ambassadeurs (30.8.1.9.1967). Les bons offices", 21.08.1967, p. 2, dodis.ch/33674. 
with the liberation movements. African nationalists were unlikely to ask the Swiss government to mediate, as they considered it to be too closely linked to the colonial power.

Switzerland's mandate to represent Portugal's interests in Senegal gave the Swiss authorities some openings to help appease the tensions in Guinea-Bissau, where the PAIGC fought the Portuguese military. Since the outbreak of this independence war in 1963, Senegalese President Léopold Sédar Senghor had tried to mediate between the PAIGC and the Portuguese government. ${ }^{15} \mathrm{He}$ repeatedly used the Swiss embassy in Dakar to contact Lisbon. Swiss diplomats were generally willing to go a little further than their mandate warranted and to serve as a two-way channel of communication between Lisbon and Dakar, as long as this did not endanger their own relations with Portugal. ${ }^{16}$ Switzerland's most important contribution to the search for a solution to the conflict in Guinea-Bissau was the organisation of a meeting between the Senegalese and Portuguese authorities in February 1970, where the possibility of ending the war was discussed. ${ }^{17}$ The initiative for this meeting came from Senghor. He asked the Swiss embassy in Dakar in late 1968 to use Switzerland's good relations with Portugal to convince the new Portuguese leader, Marcello Caetano, to meet with a Senegalese delegation. ${ }^{18}$ Preparations for the bilateral meeting were well advanced by late January 1970 when the Swiss ambassador in Senegal, Jean Richard, learned-from his American and French colleagues-that he was not only expected to host the Portuguese delegation but also to chair the discussions. Senghor had approached the US ambassador in Senegal in the hope of convincing the Nixon administration to pave the way for the prospective meeting's success. ${ }^{19}$ The French government, which represented Senegal's interests in Portugal, expected little to come of the meeting and preferred to sit back. ${ }^{20}$ The FPD empowered its ambassador to take an active role during this

15 MacQueen, "Portugal's First Domino", p. 217.

16 See notably the letter from Lucien Mossaz, head of the section responsible for the representation of foreign interest in the FPD, to the Swiss Embassy in Senegal, confidential, 10.10.1967, p. 2, SFA E2003-o6\#1979/15\#240*.

17 The Dakar meeting organised by the Swiss embassy is mentioned by MacQueen, but the author mistakenly places it in early 1971: MacQueen, "Portugal's First Domino", p. 218.

18 Letter from Pascal Frochaux, Swiss ambassador in Senegal, to Pierre Micheli, Secretary General of the FPD and head of the DPA, 11.12.1968, secret and urgent, p. 3, SFA E2001E\#1980/83\#3769*.

19 Telegram no 231 from Lewis Dean Brown, US Ambassador in Senegal, to the Secretary of State, confidential, p. 2, 23.01.1970, NARA RG 59, Subject-Numeric Files 1970-1973, POL PORT-SENEG 1/1/70, box 2557 .

20 Telegram no 251 from Lewis Dean Brown to the Secretary of State, confidential, 26.01.1970, NARA RG 59, Subject-Numeric Files 1970-1973, POL PORT-SENEG 1/1/70, box 2557. 
meeting: "The request for good offices should, in principle, be met favourably. Provided that this is the wish of both parties, our role is thus to be interpreted as broadly as possible and to assist as much as possible—obviously avoiding any partisanship." 21

Ambassador Richard was the only foreign diplomat present at the meetings between the Portuguese envoy Alexandre Ribeiro da Cunha and a Senegalese delegation headed by Foreign Minister Karim Gaye on 9-11 February 1970. During the discussions, the two sides agreed that their dialogue, which had also centred on the possibility of self-determination in Guinea-Bissau, might be continued. Afterwards, Richard was carefully optimistic that a real exchange might take place. ${ }^{22}$ However, attitudes soon hardened again and in late 1970, Gonçalo Caldeira Coelho of the Portuguese Foreign Ministry told the Swiss ambassador in Portugal that the dialogue could only be reopened if it was limited to the discussion of purely bilateral issues. ${ }^{23}$ While there are no indications of Switzerland's further implication in the search for a resolution of the conflict in Guinea-Bissau, negotiations between Lisbon and Dakar did not break off completely. Other bilateral meetings were organised by France in 1971 and by the UK just weeks before the Portuguese revolution in $1974 .{ }^{24}$ The episode of the Senegalese-Portuguese meeting in early 1970 demonstrates the limits of the Swiss government's influence to contribute to the peaceful resolution of the liberation wars in sub-Saharan Africa. While the Senegalese government was happy to delegate the logistics of the meeting to Portugal's protecting power, the US and French ambassadors in Dakar seem, at times, to have been better informed about the proceedings than their Swiss colleague. In addition, Senghor asked the US and the UK, not Switzerland, to induce Lisbon to agree to a negotiated solution to the independence war in Guinea-Bissau.

Clearly, the Swiss government's policies of aid and good offices neither influenced the course of the independence wars in the Portuguese colonies, nor were they able to diffuse the criticism of Switzerland's political and economic role in Southern Africa. The protection mandate in Senegal might have satisfied the Portuguese authorities, but it did not dispel the impression that Switzerland was on the side of the white minority regimes. In a similar vein,

\footnotetext{
21 Telegram no 8 from the FPD to the Swiss embassy in Senegal, 02.02.1970, SFA E2001E\#1980/83\#3769*. See also telegram no 6 from the Swiss embassy in Senegal to the FPD, 28.01.1970, ibid.

Telegram no 12 from the Swiss embassy in Senegal to the FPD, 12.02.1970, urgent, SFA E2001E\#1980/83\#3769*.

23 Letter from René Naville, Swiss ambassador in Portugal, to the DPA, confidential, O3.11.1970, p. 1, SFA E2OO1E\#1980/83\#3769*.

24 MacQueen, "Portugal's First Domino", pp. 219; 226-227.
} 
Bern's aid to the colonies' African populations was too limited to leave a lasting impression on the liberation movements. In a context of growing politicisation of white minority rule, the Swiss government's preparations for the independence of Angola and Mozambique were increasingly sidelined. Instead, Swiss foreign policymakers focused on countering Third World criticism. Between 1967 and 1974, Switzerland's stance on Portuguese colonialism and white minority rule was discussed at three centres of international diplomacy: the UN in New York, OAU headquarters in Addis Ababa, and at the seat of international organisations and the ICRC in Geneva. The question of how to deal with African criticism-Swiss diplomats rarely differentiated between the positions of individual governments and usually lumped them all togethercaused some friction within the Swiss federal administration. Instead of taking a clear stand on Portuguese colonialism and curbing its economic relations with Southern Africa to appease the African critics, Bern focused on the granting of limited humanitarian aid to the victims of the independence wars and took steps to improve its relations with the OAU. This, it was hoped, would enable Switzerland to compensate for its close relations with the white minority regimes, without prejudicing its economic interests.

\section{New York: Debates on Economic Collaboration at the 1967 UNGA}

Anti-colonialism was already an issue at the UNGA when Portugal was admitted to the international organisation in 1955. Yet, it was the independence of 17 African states in 196o that shifted the balance of power in the UN and paved the way, in December of the same year, for UNGA resolutions 1514 and 1542. In resolution 1514, the UNGA called for the decolonisation of all territories that had not yet attained independence. Resolution 1542 explicitly mentioned the Portuguese colonies, thereby refuting the colonial power's claim that these territories were overseas provinces. ${ }^{25}$ In the years that followed the outbreak of armed violence in the Portuguese colonies, the Afro-Asian bloc at the UN repeatedly raised the subject of Portuguese colonialism. It was instrumental to the adoption of increasingly strong resolutions against the Estado Novo regime by the Special Committee on Decolonisation and the UNGA. Nevertheless, the Salazar government could usually count on the support of the three Western

25 Reis, "Portugal and the UN", pp. 255-26o; see also Aurora Almada e Santos, "The Role of the Decolonization Committee of the United Nations Organization in the Struggle Against Portuguese Colonialism in Africa: 1961-1974", The Journal of Pan-African Studies 4:10 (2012), pp. 248-26o. 
permanent members of the Security Council. ${ }^{26}$ The Afro-Asian bloc was similarly vocal in condemning white minority rule in South Africa and Rhodesia.

Switzerland's close relations with South Africa and Portugal initially escaped the attention of the newly independent countries in Africa and the rest of the Third World. As Switzerland was a relatively small international player, had never been a colonial power, and had not joined the UN, this is perhaps not surprising. After the Rhodesian white minority government's unilateral declaration of independence from the UK in 1965, Bern also seemed to comply with the UN's Rhodesia policy in its own way. The Swiss government did not recognise Rhodesia, embargoed the export of arms to the country, and blocked the assets of the Reserve Bank of Rhodesia that were deposited at the SNB. At the same time, without referring directly to the UN call for sanctions, the Federal Council introduced the 'autonomous' and not very far-reaching measures to reduce trade with Rhodesia that were briefly outlined in the preceding chapter. $^{27}$

In 1967, however, Afro-Asian states increasingly focused on the role that trade and foreign investment played in stabilising the minority regimes and preventing the independence of dominated territories. Switzerland could no longer hide behind the great powers. In late September 1967, Bernard Turrettini, ambassador at the Office of the Permanent Observer of Switzerland to the United Nations in New York, warned the Dio that Swiss firms were likely to figure on a list of firms active in Southern Africa that a sub-committee of the Decolonisation Committee, composed of Socialist, Third World, and Finnish representatives, had just compiled. ${ }^{28}$

At the twenty-second session of the UNGA, held in 1967 , the problem of white minority rule was one of the main topics discussed. No less than seven points on the subject figured on the agenda. In the general debate, where Liberia's representative criticised the growing exports from EEC and EFTA countries to Rhodesia, Switzerland was not mentioned by name. But during discussions in different UN commissions, Swiss trade with South Africa and Rhodesia was mentioned six times. Talking about the "major Western powers"

26 Reis, "Portugal and the UN", p. 265; Lopes, West Germany and the Portuguese Military Dictatorship, pp. 15-16.

27 FPD, FDEA, proposal to the Federal Council, "Rhodesien", urgent, 13.12.1965, attached to the decree of the Federal Council, "Rhodesien", 17.12.1965, dodis.ch/31953; Ross, Neutrality and International Sanctions, pp. 165-166.

28 Letter from Bernard Turrettini, ambassador at the Office of the Permanent Observer of Switzerland to the United Nations, to the Dio, "Intérêts économiques étrangers dans les territoires coloniaux de l'Afrique australe”, 28.og.1967, SFA E2003A\#1980/85\#1971*. 
that continued to trade with South Africa in the UN's Special Political Commission, the Kenyan representative stated:

These countries include the UK, France, the US, West Germany, Japan, and Switzerland. These countries are each among the most powerful in the world and, as a group, they could certainly be a decisive factor in an issue such as apartheid. These countries not only chose not to respond to the hopes of millions of Africans, but they preferred to continue cashing in the profits from the ruthless exploitation of these same poor people. ${ }^{29}$

African delegates did not explicitly mention Switzerland's economic role in the Portuguese colonies. However, the situations in South Africa, Rhodesia, Namibia, and the Portuguese colonies were discussed interchangeably within UN frameworks. As a member of the DIO underlined in an internal note in November 1967, "[a]ll these problems being more or less interdependent, an amalgamation has progressively taken place, so that one can observe today, at the United Nations, a global approach to Southern Africa." ${ }^{30}$ Even though Switzerland's economic role in the Portuguese colonies was negligible, there was no guarantee that its links to Portugal would not be singled out in the future. Indeed, when the blacklist of firms doing business with the white minority regimes in Southern Africa was published in November 1967, it included two Swiss plantations in Mozambique. ${ }^{31}$

The criticism raised at the UNGA had an immediate effect in Bern. Concerned about Switzerland's image in Africa, the DIO organised a meeting of high-ranking members of different services of the FPD and the Trade Division on 29 November 1967. Ernesto Thalmann, at the time chief of the DIO, chaired the meeting, which he opened by stating that, although he did not want to dramatise the attacks, it was possible that they were "the prelude to a wider campaign" that might affect Switzerland's standing in different international organisations. Therefore, it was important to be proactive and to think about

29 Emphasis in original. Cited in François Pictet, chief of the DIo's United Nations and International Organisations Section, memorandum, "Nations Unies. Questions relatives à l'Afrique australe. Critiques envers la Suisse", 17.11.1967, p. 4, attached to the note from Pictet to the Secretary General of the FPD, 17.11.1967, SFA E2003A\#1980/85\#1971*.

$30 \quad$ Ibid., p. 1.

31 The firms in questions were the CCA and Copra and Cashew Nut Factories (probably Boror): letter from François de Ziegler, Office of the Permanent Observer of Switzerland to the United Nations, to the DIO, "Documentation concernant la Décolonisation", 17.11.1967, p. 2, SFA E2OO3A\#1980/85\#1971*. 
the steps to be taken in order to ward off the criticism. ${ }^{32}$ The ensuing discussion focused almost exclusively on Switzerland's economic relations with South Africa and Rhodesia, which were both more exceptional in international comparison and more heavily criticised by the Afro-Asian bloc than relations with Portugal. While all participants agreed that the African criticism voiced at the UNGA was problematic, there was a gulf in opinion between the members of the FPD and the representative of the Trade Division-Vice-Director Hans Bühler. The latter clearly prioritised Switzerland's economic and political relations with South Africa and was hostile to any measure that might impinge on these ties. Bühler refused to consider the argument of the African lobby that economic relations with white minority regimes might contribute to their stabilisation: "By trading with or investing in these regions, Switzerland has no political motive and no intention of assisting the governments in power." ${ }^{33}$ The members of the FPD, however, argued that the accusations should be taken seriously, as Third World criticism was likely to increase. Nevertheless, although some participants hinted at the possibility of a more reticent government position towards South Africa, no real change in policy was decided. Instead, the leaders of the FPD services agreed to prepare a file on Swiss policy in Southern Africa that would help Swiss ambassadors abroad respond to further allegations. Lastly, the participants returned to their standard panacea whenever relations with Africa were concerned; they discussed the granting of humanitarian aid in order to foster political goodwill towards Switzerland. ${ }^{34}$

The question of aid for Southern Africa was the focus of intense debate between the different sections of the FPD responsible for aid. As a result of the accusations levelled against Switzerland at the UN, the STC prepared to increase its activities in the independent states of Southern Africa: Lesotho, Zambia, Malawi, and Tanzania. ${ }^{35}$ Multilateral aid in the form of a Swiss contribution to different UN programmes in favour of the victims of racial oppression, such as the UN Trust Fund for South Africa or the UN Training Programme for South Africans, was more controversial than bilateral aid. Despite

32 Statement of Ernesto Thalmann, in François Pictet, memorandum, "Relations de la Suisse avec l'Afrique australe. Réunion inter-départementale du 29 novembre", 13.12.1967, p. 1, SFA E2005A\#1980/82\#132*; see also the note from Pictet to the sTC, "Afrique australe", 14.11.1967, ibid.

Statement of Hans Bühler, Vice-Director of the Trade Division, in François Pictet, memorandum, "Relations de la Suisse avec l'Afrique australe. Réunion inter-départementale du 29 novembre", 13.12.1967, p. 1, SFA E2005A\#1980/82\#132*.

34 Ibid., pp. $2-3$.

35 Note from Richard Pestalozzi to the Dio, "Fonds betreffend Südafrika'. Ihre Notiz vom 15. Januar 1968”, 19.01.1968, dodis.ch/33771. 
Ambassador Turrettini's frequent insistence that such donations might compensate for Switzerland's close relations with the white minority regimes and the fact that other Western states had already made financial contributions, the DPA was opposed to these programmes because of their political nature. ${ }^{36}$ This scepticism was shared by the STC, which was, in any case, doubtful that a financial contribution would really allow the Swiss government to buy its way out of criticism. ${ }^{37}$ The reluctance to contribute to the UN funds was probably also a reflection of a general aversion to multilateral aid, which reduces individual donors' control over aid and its political benefits. The DIO, most closely concerned with UN affairs, also had some doubts about the special funds, but advocated an additional contribution to the Office of the United Nations High Commissioner for Refugees (UNHCR) in favour of South African refugees: "This form of aid, granted to a virtually apolitical organisation which endeavours at all times to make the humanitarian aspect predominate in the examination of problems, would meet our agreement, as we would like to depoliticise potential aid as much as possible." ${ }^{38}$ The Swiss authorities' concern about avoiding programmes that were perceived to be politically motivated to make a donation for political reasons appears more than a little paradoxical. It is indeed striking how FPD officials underlined the non-political nature of humanitarian aid at the same time that they justified this aid with political motives. However, for the time being, no such Swiss contribution was made.

The criticism of Switzerland's role in Southern Africa voiced at the 1967 UNGA was no one-time occurrence that could easily be put aside. The insistence on decolonisation and opposition to white minority rule were positions that were, at least verbally, supported by all African leaders. Bernard Turrettini warned the head of the department in February 1968 that African states were convinced that this cause was just and would not give up. He feared that Switzerland's economic relations with the minority regimes in Southern Africa might endanger the credibility of its neutrality. ${ }^{39}$ As a consequence, Federal Councillor Willy Spühler expressed his concern about growing Swiss investment in South Africa to the SNB in March 1968. He was, however, firmly

36 Gérard Fonjallaz, Dio, memorandum, "Aide aux victimes de l'apartheid", og.10.1967, SFA E2003A\#1980/85\#1970*.

37 Note from Richard Pestalozzi to the Dio, "'Fonds betreffend Südafrika'. Ihre Notiz vom 15. Januar 1968", 19.01.1968, dodis.ch/33771.

38 Note from Ernesto Thalmann to the DPA, "Aide aux victimes de l'apartheid - Participation éventuelle de la Suisse à un Fonds des Nations Unies", 25.11.1967, p. 4, SFA E2003A\#1980/85\#1970*.

39 Letter from Bernard Turrettini to Federal Councillor Willy Spühler, 20.02.1968, p. 3, SFA E2003A\#1980/85\#1971*. 
rebuffed. Two months later, Ambassador August Lindt made a statement condemning Apartheid at the UN International Conference on Human Rights in Tehran.${ }^{40}$ While the impact of African criticism on the FPD's approach towards South Africa was admittedly very modest, no such change occurred with regard to Portuguese colonialism. Still, in April 1968, the Dio did instruct Swiss delegations to abstain from all votes on the exclusion of Portugal from intergovernmental organisations and conferences. Although Bern recognised Portuguese sovereignty in Africa, publicly defending Portugal's legal right to its colonies would have made Switzerland a supporter of the colonial regime in the eyes of the Third World. This was deemed too risky. ${ }^{41}$ "De facto, we are only a 'moral great power' in Europe, in Africa we still have to prove this", Swiss ambassador Hans Karl Frey, stationed in Kenya, warned his colleagues in September $1969 .{ }^{42}$ Later the same month, the Tanzanian representative to the UN, while highlighting Western collaboration with the white minority regimes during a plenary meeting of the UNGA, mentioned Swiss interests in the construction of the Cabora Bassa dam in Mozambique, Nestlé's activities in Angola, and Switzerland's non-compliance with the UN sanctions policy towards Rhodesia. ${ }^{43}$ The Swiss government had to face even more pressure when the OAU emerged as a new collective actor in the international discussion about Switzerland's role in Southern Africa.

\section{Addis Ababa: OAU Diplomacy in Bern, 1972}

In the early 1970s, African censure of Portuguese colonialism and white minority rule in Southern Africa reached a new intensity. Addis Ababa, the headquarters of the OAU, became a second centre of African criticism of Switzerland's political and economic relations with the white minority regimes. In April 1969, thirteen leaders of east and central African states had published the Lusaka Manifesto, which called on the help of all governments to convince the

$40 \quad$ Kreis, Die Schweiz und Südafrika, p. 80; on the background of Lindt's apartheid declaration, see Thomas Widmer, Christian Hirschi, Stabilität im Wandel. Gestaltung der schweizerischen Südafrikapolitik von 1968 bis 1994, Zürich: Verlag Rüegger, 2005, pp. 76-94. Ernesto Thalmann, "Instructions aux délégations suisses dans les conférences internationales au sujet de l'admission et de l'exclusion de certains pays", 10.04.1968, pp. 4-5, dodis.ch/33555.

42 Statement of Hans Karl Frey, Swiss ambassador in Kenya, minutes of the Annual Conference of Swiss Ambassadors 03.09.1969-05.o9.1969, 10.10.1969, p. 15, dodis.ch/30859.

43 Telegram no 187 from the Permanent Observer of Switzerland to the United Nations to the FPD, 24.09.1969, SFA E2003A\#1980/85\#1971*. 
Portuguese, South African, and Rhodesian regimes to end racial discrimination and minority rule. The OAU and the UN ratified this manifesto in that very year. It was the expression of a moderate strand of African discourse on liberation, which focused on peaceful change and dialogue with the racist regimes. It contrasted with a more militant strand calling for violent action that gained increasing influence in the following years. Subsequently, the October 1971 Mogadishu Declaration of east and central African states concluded that there was no solution left, other than to support the armed struggle. ${ }^{44}$ In parallel with continued pressure through various UN bodies, independent African governments increased their lobbying through the OAU; delegations from Africa's continental organisation toured NATO members and other Western European states in order to convince their governments to stop collaborating with the white minority regimes.

When the OAU started to criticise Switzerland's role in Southern Africa in 1970, FPD leaders in Bern were not pleased to have to justify their position to a second organisation and showed a certain distrust of their African interlocutors. In November 1970, the OAU's secretary, Guinean Boubacar Diallo Telli, approached the Swiss ambassador in Ethiopia, Heinz Langenbacher, and asked to discuss Switzerland's "sins" in Southern Africa with him. ${ }^{45}$ The ambassador's superiors warned him "to exercise the greatest possible restraint" towards Diallo Telli, as "there is little doubt that all he cares about is denouncing Switzerland to the OAU member states and others as a 'collaborator." 46 Yet, due to the numeric weight of independent African states in international organisations and their combined economic importance for Switzerland, Bern could ill afford to simply ignore the OAU. African pressure and especially the threat of negative economic consequences, had already been decisive in Switzerland's closure of its consulate in Rhodesia in March 1970. Switzerland was the last state, aside from South Africa, Portugal, and the Greek military dictatorship, to close its consulate in Salisbury ${ }^{47}$ This, together with Switzerland's

44 Lopes, West Germany and the Portuguese Military Dictatorship, pp. 17-30.

45 Telegram no 44 from the Swiss Embassy in Ethiopia to the FPD, 17.11.1970, SFA E2003A\#1984/84\#672*.

46 Letter from Michael Gelzer, Deputy Chief of the DPA, to the Swiss Embassy in Ethiopia, "Dokumentation über die Beziehungen der Schweiz mit Australafrika", 27.11.1970, confidential, p. 2, SFA E2003A\#1984/84\#1748*.

47 In its proposal to the Federal Council to close the consulate, the FPD mentioned notably the call for sanctions against Western states entertaining diplomatic relations with the Rhodesian regime voiced at the OAU Council of Ministers in early March: FPD, proposal to the Federal Council, "Schweizerisches Konsulat in Rhodesien", 13.03.1970, SFA E2001E\#1980/83\#3819*. According to a member of the British embassy in Bern, the 
non-participation in the UN sanctions against Rhodesia, caused quite a stir. In Addis Ababa, Langenbacher was regularly confronted with new allegations against Switzerland. In April 1971, for example, Diallo Telli warned him that Switzerland's image in Africa was waning because its principles of neutrality and humanitarianism were not applied in Southern Africa. Langenbacher, who liked and respected Diallo Telli, closed his report of this conversation with a passionate appeal to take the OAU and its position seriously. ${ }^{48}$ Like his colleague Turrettini in New York, he became a spokesman for a more active Swiss policy in this region that was more attentive to the demands of independent African governments.

In June 1971, the announcement that the OAU intended to visit Switzerland, Japan, and several NATO members to discuss these states' relations with the white minority regimes galvanised the Swiss federal administration. The planned visits were a continuation of the tour of Washington, London, Paris, Bonn, and Rome undertaken the preceding year by Zambian President Kenneth Kaunda, who had become chairman of both the OAU and NAM in mid$1970^{49}$ For the head of the FPD's newly founded Political Secretariat, Albert Natural, the visit was an occasion to re-examine Switzerland's relations with Southern Africa and its policies on the main problems in this region: Apartheid, Namibia and Rhodesia, and the Cabora Bassa dam in Mozambique. ${ }^{50}$

Preparations for the visit began immediately. Ambassador Langenbacher reported to the DPA that the OAU delegates had been disappointed by their visits to Washington, London, and Bonn. They had praised their reception in Paris and Rome: "This impression was determined less by factual concessions than by the cordial atmosphere that Rome and Paris knew to create and to which the African responds particularly well." ${ }^{51}$ This racist and patronising comment was reproduced in a memorandum on the Kaunda visits in other Western

closure was a result of direct threats of the governments of the Congo and Cameroon to abrogate air service agreements with the Swiss national airline, Swissair, if the Swiss government maintained its consulate in Salisbury: Letter from G. V. Britten, Chancery of the British Embassy in Switzerland, to the Rhodesia Political Department, o3.04.1970, The National Archives, Kew, UK (TNA) FCO $36 / 726$.

48 Political Report (PR) no 10 from Heinz Langenbacher, Swiss ambassador in Ethiopia, "Africa und die Schweiz", 02.04.1971, p. 4, SFA E2300-01\#1977/29\#3*.

49 Lopes, West Germany and the Portuguese Military Dictatorship, p. 22.

50 Note from Albert Louis Natural, head of the newly formed Political Secretariat, to the heads of division in the FPD and the Trade Division, "Visite d'une délégation de l'OUA en Suisse: relations avec l'Afrique australe", 02.07.1971, confidential, p. 2, SFA E2001E-O1\#1982/58\#440*.

$5^{1}$ Letter from Heinz Langenbacher to the DPA, "Besuch einer OAU-Delegation in Bern", o8.07.1971, confidential, p. 2, SFA E2OO1E-o1\#1982/58\#440*. 
capitals and would set the tone for the whole organisation of the visit. ${ }^{52}$ The guidelines for the first interdepartmental meeting on preparing for the OAU visit, held on 24 August 1971, are typical of the condescending way in which the Swiss authorities regarded the OAU delegates and their lack of consciousness that Switzerland's position in Southern Africa might be perceived as problematic. As Edouard Brunner, deputy chief of the Political Secretariat, stated early in the meeting, "[t]he important thing is not so much what is said to the Africans, but how it is said."53 He asserted that there was no need to justify Switzerland's role in Southern Africa. The FPD's Secretary General repeatedly stressed the importance of Switzerland's economic exchanges with South Africa and insisted that nothing be said or done during the OAU representatives' visit that might offend the Portuguese or South African governments. ${ }^{54}$ In order to improve Switzerland's relations with the OAU, it was decided to receive the delegates as honoured guests and to focus on creating a good atmosphere during the visit. A working group of FPD and FDEA members was tasked with compiling an information file for the attention of the visitors, which explained Swiss policies in areas that might be criticised by the OAU. ${ }^{55}$

The decision to welcome the African visitors with all honours stemmed from serious concerns about the possible negative effects of ignoring the OAU and its demands. The question of white minority rule united African governments of all political couleurs. On the one hand, their persistent criticism of Switzerland's position in Southern Africa might impair the country's image in the Third World and endanger the credibility of its neutrality. On the other hand, the newly independent African states also held some economic power and concerted action by them could potentially damage Switzerland's economic interests in those states. The OAU's written report following its first round of visits to NATO capitals in mid-1970 had envisaged the possibility of imposing economic and political sanctions on states that refused to break off relations

52 Memorandum by Jean-Jacques Indermühle, DPA, "Résumé des visites que la Délégation de l'OUA a faites en automne 1970 auprès des Gouvernements américain, anglais, allemand, français et italien", 19.07.1971, p. 4, SFA E2001E-o1\#1982/58\#439*.

53 Emphasis in original. Statement of Edouard Brunner, deputy chief of the Political Secretariat, in Jean-Jacques Indermühle and Hansrudolf Hoffmann, FPD, "Vorbereitende Sitzung vom 24.8.1971 bezüglich Besuchs der OAU-Delegation in der Schweiz”, no date, p. 1, attached to the note from Albert Louis Natural to the heads of division in the FPD and the Trade Division, "Visite d'une délégation de l'OUA en Suisse: relations avec l'Afrique australe", 07.09.1971, SFA E2001E-01\#1982/58\#440*.

54 Statements of Ernesto Thalmann, Secretary General of the FPD, ibid., pp. 2, 13.

55 Note from Ernst Henri Léchot to Hans Bühler, "Mission OUA", 31.08.1971, SFA E2001E-o1\#1982/58\#440*. See also the section on the Cabora Bassa dam in chapter 3. 
with the white minority regimes. During a preliminary visit to Bern in December 1971, OAU Secretary Diallo Telli warned that the OAU would draw its conclusions after the completion of the second round of visits planned for 1972. These might include the boycott of states that continued to trade with South Africa, Rhodesia, and Portugal. Nevertheless, in their dealings with Switzerland, OAU leaders focused on dialogue rather than confrontation. Prior to the Portuguese Revolution, OAU resolutions criticising Western states' policies on Southern Africa never mentioned Switzerland. During his talk with the FPD's Secretary General in December 1971, Diallo Telli insisted that the visit was "a mission of goodwill, friendship" and stated its goals in moderate terms: "it is important that the countries we visit become aware of the problem, that they reflect, that they weigh up the pros and cons of their current policies, not only in terms of international morality but also in terms of their economic and commercial interests in the medium and long term." 56

During the preparatory phase, FPD officials hardly ever referred to the foreign policies of the European neutral states, particularly Sweden and Austria. While the latter was not on the OAU delegation's itinerary, the former's position on national liberation was very different from that of Switzerland. In Sweden, the liberation struggles in Southern Africa received great popular and governmental support. Following initial contact between the Swedish authorities and Portuguese African nationalists in the 196os, the Swedish parliament endorsed official humanitarian aid for the Southern African liberation movements in May 1969. Non-military support was extended to the PAIGC in Guinea-Bissau from mid-1969 and, in decreasing importance, to FRELIMO and the MPLA, from 1971. Together with the USSR, Sweden was one of the most generous donors to the PAIGC. Although the Swedish government did not formally recognise these liberation movements, it treated them increasingly like governments-in-waiting. ${ }^{57}$ Unlike their Swiss counterparts, the Swedish authorities did not consider their policy of neutrality to be incompatible with taking a clear position against colonialism and white minority rule. Well informed of the course of the OAU's visit to Sweden in October 1971, DPA leaders realised

$5^{6} \quad$ BRE, "Entretiens du jeudi 23 décembre 1971 de Monsieur l'Ambassadeur Thalmann avec le Secrétaire général de l'OUA Monsieur Diallo Telli (DT)", 27.12.1971, p. 3, attached to the note from Jean-Jacques Indermühle to to the heads of division in the FPD and the Trade Division, "Visite d'une délégation de l'OUA", 28.12.1971, SFA E2001E-o1\#1982/58\#440*. See also the letter from Heinz Langenbacher to the DPA, "Besuch einer OAU-Delegation in Bern", o8.o7.1971, confidential, p. 1-2, ibid.

57 See Sellström, Sweden and National Liberation in Southern Africa. Volume II: Solidarity and Assistance, pp. 32-125, particularly p. 64. 
that the Swedish example could not serve as inspiration for Switzerland. ${ }^{58}$ This opposing model of a neutral foreign policy on Southern Africa increasingly turned into a liability for Switzerland. Reporting on the UN Security Council's first meeting on the African continent in Addis Ababa in January and February 1972, Heinz Langenbacher noted that Sweden "repeatedly received a good Africa-mark (also by liberation movements)". ${ }^{59}$

The OAU delegation, presided over by the new OAU chairman, Mauretanian President Moktar Ould Daddah, and comprising high-ranking members of the OAU and the governments of Algeria, Cameroon, Kenya, Mali, Mauritania, and Zambia arrived in Bern on 18 April 1972. In his welcome speech, Swiss President Nello Celio explained Switzerland's foreign policy on Southern Africa. This was guided by three principles: First, the principle of non-interference in the internal affairs of other states, which was an important part of the Swiss conception of neutrality. Secondly, the President underlined Switzerland's commitment to the equality of all people and its rejection of all forms of discrimination. Finally, Celio mentioned the principle of liberalism to explain that the Swiss government could not intervene in the economic sector as it saw fit. ${ }^{60}$ Commenting mockingly on Switzerland's "African policy (or absence of policy)", Eduardo Manuel Fernandes Bugalho, the Portuguese ambassador in Bern, observed the contradictions inherent in the compilation of these principles when reporting back to his government a few days later: "It is certainly curious how the moral reference, with which they [the Swiss] wanted to a certain extent to satisfy the African interlocutor, was squeezed between the two political principles, which themselves exclude any action that could be justified by the acceptance of the other [moral principle]."61

On the following day, talks were held in a pleasant and friendly atmosphere, according to Swiss observers. In his introductory speech, Ould Daddah stated clearly what the OAU expected from Switzerland: "We would like to see the Swiss Government try to limit the activities of its nationals in the countries of concern to us." After explaining that economic collaboration with the white minority regimes in Southern Africa was short-sighted and that the Swiss

$5^{8} \quad$ See the letter from René Faessler, Swiss Ambassador in Sweden, to the DPA, "Visite à Stockholm de la délégation OUA", 28.10.1971, p. 1, SFA E2001E-o1\#1982/58\#440*.

59 PR no 3 from Heinz Langenbacher, "Die Grenzen der Uno: Die Afrika-Debatte des Sicherheitsrates in Addis Abeba (28.1.-4.2.1972)", 05.02.1972, p. 11, SFA E2300-o1\#1977/29\#3*.

6o Address by Nello Celio, Swiss President, "Allocution prononcée par le Président de la Confédération, M. Nello Celio, à l'occasion du dîner offert en l'honneur de la délégation de l'OUA, le 18 avril 1972", no date, pp. 1-2, SFA E2001E-o1\#1982/58\#440*.

61 Telegram no $9(10,11)$ from Eduardo Manuel Fernandes Bugalho, Portuguese ambassador in Switzerland, to the MNE, 22.04.1972, pp. 1-2, AHD, PEA, Pr. 320.8o, box 712. 
business sector should be encouraged to redirect its investments to independent African states, he turned to his second subject: "I come back to the humanitarian issue. Switzerland has distinguished itself through its humanitarian action. It is not by chance that it is the birthplace of the Red Cross [...]. That is why we have come to ask Switzerland to help the liberation movements on a humanitarian and social level." 62

The head of the Swiss delegation, Federal Councillor Pierre Graber, once again underlined the Swiss government's limited influence in economic affairs. The discussion soon centred on different options for direct Swiss support for the liberation movements and the refugees of the independence wars. The OAU delegation was well prepared. The Executive Secretary of its Liberation Committee presented different aid projects organised by the OAU and the liberation movements, specifying their needs. Graber argued that as a longstanding permanent neutral state, Switzerland had to adhere more strictly to the principles of neutrality than the other European neutrals. This constrained the Swiss government's scope for action. Nevertheless, he informed the OAU delegation that the Swiss government had decided to contribute CHF 75, OOO to the UN Trust Fund for South Africa. The Federal Councillor also promised that this humanitarian action would be continued and that the DPA would examine in what way direct Swiss aid would be possible. ${ }^{63}$ The news of Switzerland's contribution to the Trust Fund was well received by the OAU delegation and Ould Daddah personally announced it at a press conference during the visit. ${ }^{64}$

After the departure of the OAU delegation on 20 April, FPD leaders declared themselves satisfied. They particularly highlighted the moderate and reasonable stance of the African delegates. ${ }^{65}$ According to Heinz Langenbacher, the African delegates also gave the visit a positive verdict. The ambassador reported that the Swiss government's willingness to consider granting humanitarian aid to the victims of the liberation struggle, the friendly reception of the delegation, and the honest and realistic discussions both with the Swiss

62 Statement of Moktar Ould Daddah, Mauritanian president and chairman of the OAU, in Jean-Jacques Indermühle, Hanspeter Strauch, "Procès-verbal des entretiens du 19 avril 1972 avec une délégation de l'OUA dirigée par M. Ould Daddah, Président en exercice de l'OUA et Chef d'Etat mauritanien", no date, pp. 4-5, SFA E2001E-o1\#1982/58\#440*.

63 Ibid., pp. 6-16.

64 Letter from Gaspard Bodmer, DIO, to the Permanent Observer of Switzerland to the UN, "Beiträge an verschiedene Institute der Vereinten Nationen (UNITAR, UNRISD, Institut de recherches des Nations Unies pour la défense sociale, Fonds d'affectation spéciale des Nations Unies pour l'Afrique du Sud)", 02.05.1972, SFA E2001E-01\#1982/58\#440*.

65 Telegram from the FPD to the Swiss embassies in Africa and to the Office of the Permanent Observer of Switzerland to the UN, 24.04.1972, p. 2, SFA E2001E-o1\#1982/58\#440*. 
authorities and with business people were appreciated. Consequently, it seemed that Switzerland's image in Addis Ababa had improved—at least for the time being. ${ }^{66}$ The Swiss press showed little interest in the visit, especially in German-speaking Switzerland. ${ }^{67}$ Press reports from French-speaking Switzerland that mentioned a Swiss promise of humanitarian aid for African liberation movements did, however, lead to complaints from the South African and the Portuguese embassies in Bern. In order to prevent further controversy, the FPD warned its own ambassadors in South Africa and Portugal to be careful when mentioning possible Swiss aid. ${ }^{68}$

The Swiss government's strategy of focusing on low-cost political goodwill gestures such as the warm reception given to the delegation and the granting of humanitarian aid to draw attention away from their unwillingness to change their Southern Africa policy was successful. Although Bern made very few concessions, the April 1972 visit was a small turning point in Switzerland's Southern Africa policy. It increased the government's awareness of the risks to its image of its non-committal stance on white minority rule and encouraged it to be even more careful to keep a low profile. The visit also spurred a renewed effort to aid the Southern African populations. As in 1967-1968 after the UNGA criticism of Switzerland, Swiss foreign policymakers considered humanitarian aid a suitable instrument to improve the image of their neutrality in Africa.

While preparing for the OAU visit, the DIO had re-examined the matter of a possible Swiss contribution to UN programmes in favour of Southern African refugees that had been shelved in 1968. As the forthcoming visit placed Switzerland in the limelight, the service judged a goodwill gesture opportune. The Swiss Anti-Apartheid Movement and Ambassador Langenbacher in Addis Ababa also endorsed a Swiss contribution to the UN Trust Fund for Africa. The Federal Council approved this in February 1972. The announcement of the decision was delayed until the visit of the OAU in April in order to boost its impact. ${ }^{69}$ Despite Pierre Graber's promise of further aid, little happened after

66 Letter from Heinz Langenbacher to the Political Secretariat, "OAU-Delegation", 07.06.1972, SFA E2OO1E-O1\#1982/58\#440*.

67 Gregor Kündig, FPD, memorandum, "Berichte und Kommentare in der Schweizer Presse zum Besuch einer Delegation der OAU-Staaten in der Schweiz am 18. und 19.4.1972", June 1972, dodis.ch $/ 36362$.

68 Telegram from the FPD to the Swiss embassies in South Africa and Portugal, 21.04.72, urgent, p. 1, SFA E2001E-o1\#1982/58\#440*. See also telegram no 9 (10, 11) from Eduardo Manuel Fernandes Bugalho to the MNE, 22.04.1972, p. 3-5, AHD, PEA, pr. 321.80, box 712.

69 Peter Friedrich, Dio, memorandum "Fonds d'affectation spéciale des Nations Unies pour l'Afrique du Sud - Contribution éventuelle de la Suisse", 13.10.1971, SFA E2001E-ol\#1982/58\#440*; letter from Gaspard Bodmer to the Permanent Observer of 
the OAU delegation left Bern. The DIO was hardly proactive and seemed content to wait for the OAU to provide further information on its humanitarian programme. ${ }^{70}$ At the same time, Bern continued to be torn between the wish to grant aid in order to appease the African critics of its policy in Southern Africa, and concern that aid might be equated to support for national liberation.

The personal initiative of ambassador Heinz Langenbacher was mainly responsible for the only further action in favour of Southern African refugees before the Carnation Revolution. In February 1973, he proposed that the Swiss government finance a seminar on refugees in Africa that the OAU's Bureau for the Placement and Education of African Refugees (BPEAR) planned to hold in the second half of 1973. The event would bring together representatives of African governments, liberation movements, and international and regional organisations. ${ }^{71}$ FPD staff members worried that sponsoring this seminar might make it look as if Switzerland supported the liberation struggle in Southern Africa. To avoid possible criticism by the white minority regimes and the part of the Swiss population that was well disposed to South Africa, they asked the UNHCR to serve as an intermediary for Switzerland's contribution. "By proceeding in this manner, this operation could be listed, in our statistics and reports, as a completely unproblematic donation to the HCR", a department member wired to Langenbacher in May $1973 \cdot{ }^{72}$ With the consent of the UNHCR, the FPD agreed to cover the total cost of the seminar, \$25, OOO (CHF $78,900) \cdot{ }^{73}$ Discussions during the seminar were highly political, justifying the

Switzerland to the UN, "Beiträge an verschiedene Institute der Vereinten Nationen (UN ITAR, UNRISD, Institut de recherches des Nations Unies pour la défense sociale, Fonds d'affectation spéciale des Nations Unies pour l'Afrique du Sud)", 02.05.1972, ibid.

70 Letter from René Keller, chief of the DIO, to the Swiss embassy in Ethiopia, "Aide humanitaire éventuelle aux mouvements africains de libération", 27.06.1972, SFA E2001E-o1\#1982/58\#439*; letter from Heinz Langenbacher to the DiO, "Ev. Humanitäre Hilfe für Befreiungsbewegungen”, 24.11.1972, SFA E2003A\#1984/84\#672*; letter from Langenbacher to the DIO, "Ev. Humanitäre Hilfe für Befreiungsbewegungen", 01.02.1973, SFA E2003A\#1988/15\#573* and handwritten notes on this document.

71 Letter from Heinz Langenbacher to the DIO, "OAU: Flüchtlingshilfe", 10.02.1973, SFA E2003A\#1988/15\#570*; letter from Langenbacher to the DIO, "OAU-Flüchtlingshilfe", 27.02.1973, ibid.

72 Telegram no. 28 from the FPD to the Swiss embassy in Ethiopia, 22.03.1973, SFA E2003A\#1988/15\#570*.

73 The Swiss contribution was later reduced to $\$ 15^{\prime}$ OOO ( $\mathrm{CHF} 47^{\prime} 3 \mathrm{OO}$ ), as the OAU covered the rest through its own budget: note from François Pictet to the chief of the DiO, "Séminaire de l'ouA sur les réfugiés", 27.03.1973, SFA E2003A\#1988/15\#570*; telegram no. 38 from the FPD to the Swiss embassy in Ethiopia, 04.04.1973, ibid. The sums have been converted to $\mathrm{CHF}$ using the exchange rates indicated in Officer, "Exchange Rates Between the United States Dollar and Forty-one Currencies". 
FPD's earlier reluctance. Accordingly, the Swiss embassy in Ethiopia recommended that Switzerland keep its distance from the BPEAR in the future and collaborate rather with the UNHCR in the matter of refugees. ${ }^{74}$ Thus, Swiss aid to Southern Africa remained limited.

The opening of the Executive Secretariat of the OAU in Europe in Geneva in late 1973, first discussed between the OAU and the Swiss government during the 1972 Bern visit, was the most significant result of this diplomatic effort. In the second half of 1971, the DIO had read in a UN document that the OAU wished to establish an office in Western Europe, "so that liaison can be maintained with the Specialised Agencies, anti-apartheid movements and other organisations with regard to action against apartheid." 75 The DIO considered it to be in Switzerland's interest for this mission to be located in Geneva. It was a sign of courtesy towards the OAU, as it would facilitate the organisation's contact with the numerous international organisations established in the city. In addition, it would allow an intensification of Switzerland's contact with the OAU and potentially boost Swiss-African economic relations. At the same time, DIO officials wished to control the principal political organisation on the African continent, as they noted in August 1972: "such an information office would be easier for us to control and to 'hem in' than an information office without official status, which could indulge in disagreeable propaganda without us having the means to intervene." 76 The OAU bureau was granted the same official status and resulting privileges as any other liaising mission in Geneva. Consequently, its delegation was bound by international diplomatic law and prohibited from undertaking "any activity which may be qualified as interference in the internal affairs of the host country, or directed against a third state in such a way as to damage the interests of the host country itself."77 In June 1974, the OAU's Council of Ministers was satisfied with the positive results the Executive Secretariat of the OAU in Europe had achieved in its first year. It encouraged Afri-

74 Marcus Kaiser, Swiss embassy in Ethiopia, report, "Bericht über das Zweite Flüchtlingsseminar des OAU Bureau for Placement and Education of African Refugees (BPEAR) vom 26.11. - 1.12.1973 in Addis Ababa", confidential, no date, attached to the letter from Heinz Langenbacher to the DIO, "Flüchtlingsseminar OAU", 06.12.1973, SFA E2OO3A\#1988/ $15 \# 570^{*}$.

Emphasis in original. Cited in the note from Gaspard Bodmer to the chief of the DIO, "Ouverture d'une mission ouA à Genève", 11.08.1972, p. 1, SFA E2003A\#1984/84\#672*.

76 Ibid., p. 2. See also Gaspard Bodmer, memorandum, "Visite à Berne d'une délégation de l'OUA et établissement d'une mission permanente de l'OUA à Genève", 14.10.1971, dodis.ch/36376; decree of the Federal Council, "Statut de la délégation permanente de l'Organisation de l'Unité Africaine”, 05.09.1973, dodis.ch/39298.

77 Hanspeter Strauch, aide-mémoire, "Ouverture, par l'OAU, d'une Mission permanente à Genève", no date [12.02.1973], p. 2, dodis.ch/39296. 
can ambassadors in Europe to collaborate with the Executive Secretariat and requested the latter to "follow its political action with European Governments on questions of decolonization and the struggle against apartheid and racial discrimination" and to "strengthen its information activities and its cooperation with the non-governmental organizations engaged in the struggle against colonialism and apartheid."78

With regard to Switzerland's policy in the Portuguese colonies, FPD leaders were even more careful to keep a low profile after the OAU visit. Thus, Michael Gelzer, the deputy chief of the DPA, decided in March 1972 not to appoint a career consul to Angola, although Switzerland's economic interests and the number of Swiss residents in the country would have justified this. Since the OAU and the UN might interpret the upgrading of Switzerland's diplomatic representation as a sign of support for the Portuguese colonial regime, Gelzer preferred discretion to practicalities. ${ }^{79}$ For the same reason, in January 1973, he cancelled two official trips by the Swiss ambassador in Lisbon, one to Angola and one to Mozambique, that had already been approved by the AD: "Because of the agitation against Portugal's colonial policy, which is, as is well known, one of the main subjects of UN debates, it is my opinion that we should avoid any gesture which could be interpreted as a recognition of Portugal's colonial territorial claims." 80 On this issue, the FPD adopted the same line as the Nordic countries, which prevented their representatives in Lisbon from accepting the Portuguese authorities' customary open invitation to every newly-arrived ambassador to visit the African colonies. While the French, British, and US ambassadors, as well as those from several Latin American states, had visited Angola and Mozambique by the middle of 1973, and their Austrian and Belgian colleagues accepted the invitation, the Dutch, Norwegian, and Danish governments refused. Considering the Social-Democratic Swedish government's open condemnation of Portuguese colonialism, it is not surprising that the Swedish ambassador does not seem to have received an invitation. ${ }^{81}$

78 Resolution CM/Res 345 (XXIII) of the OAU Council of Ministers' 23rd Ordinary Session from 6 to 11 June 1974, "Resolution Executive Secretariat of the OAU in Europe (Geneva)", https://au.int/sites/default/files/decisions/9582-council_en_6_15_june_1974_council_ ministers_twenty_third_ordinary_session.pdf (13 January 2021).

79 Note from Michael Gelzer to Antonino Janner, head of the AD, "Schweizerisches Konsulat in Luanda (Angola)", 15.03.1972, SFA E2001E-o1\#1982/58\#6127*.

8o Note from Michael Gelzer to the AD, 11.01.1973, p. 1, SFA E2001E-o1\#1987/78\#4648*.

81 Letter from S. F. St. C. Duncan, British Embassy in Portugal, to Barbara Richards, Central and Southern African Department (CSAD) of the FCO, "Tours of Heads of Missions of Portuguese Africa", 27.06.1973, pp. 1-2, TNA FCO 45/1316. 
Swiss foreign policymakers continued to be faithful to the 1963 instructions to keep their distance from representatives of African liberation movements. In early June 1973, Federal Councillor Pierre Graber refused to meet an MPLA member on the basis that the Swiss government could not have official relations with a liberation movement as long as it had normal diplomatic ties to Portugal. ${ }^{82}$ Later in the same month, the DIO issued guidelines that Swiss delegations to international organisations should abstain from any votes aimed at granting observer status to liberation movements. ${ }^{83}$ The dilemma between Bern's selective interpretation of neutrality, which resulted in a pro-Portuguese position, on one hand, and the realisation that decolonisation was inevitable and public support of Portugal might endanger relations with the colonies' future rulers and independent Third World governments, on the other hand, did not make for easy policy choices. Consequently, the DPA was engaged in a careful balancing act, which occasionally interfered with the efficient running of its foreign services.

The positive evaluation of the OAU visit to Bern should not obscure the fact that the Swiss government did little more than "to listen and utter fine words", as a French observer noted. ${ }^{84}$ Instead of serving as an opportunity to set out a more coherent Swiss policy on Southern Africa, one that gave more emphasis to the people oppressed by white minority rule, the visit confirmed Bern's unwillingness to reconsider Switzerland's economic relations in this region. In this sense, the meetings with OAU delegates were a missed chance to adapt Switzerland's position and prepare for decolonisation. The continued neglect of the African liberation movements, in particular, would have negative consequences after the independence of Angola and Mozambique. In the short term, however, the Swiss government successfully used the promise of humanitarian aid to improve relations with the OAU. The fact that the OAU delegates themselves focused on aid by appealing to Switzerland's humanitarian tradition and did not request a fundamental change in the country's economic role in Southern Africa suggests that they knew their interlocutors well enough to be able to form realistic expectations of the possible outcome of the visit.

82 Letter from Alfred Reinhard Hohl, DPA, to the Schweizerische Arbeitsgruppen für Entwicklungspolitik (Swiss Working Groups for Development Policy, SAFEP), 07.06.1973, SFA E2001E-01\#1987/78\#4648*.

83 Note from François Pictet to René Keller "Participation des mouvements de libération aux activités des organisations internationales", 21.06.1973, dodis.ch/38891, and handwritten comments indicating agreement.

84 Letter from Bernard Dufournier, French ambassador in Switzerland, to Maurice Schumann, French Foreign Minister, "Mission de l'OUA à Berne", 26.04.1972, p. 2, Centre des Archives diplomatiques, La Courneuve/Paris, France (CAD) 206QO/169. 


\section{Geneva: The Status of Liberation Movements at the 1974 ICRC International Humanitarian Law Conference}

In 1973 and 1974, a new front in the struggle for national liberation in Southern Africa opened in Geneva, at the headquarters of the ICRC, in the field of international humanitarian law ( $\mathrm{IHL}$ ). In the late 196os, a movement advocating the revision of international law applicable in armed conflict had gained momentum. New forms of conflict, such as independence wars and guerrilla warfare, and the use of new weapons, such as napalm, had exposed the limits of the Geneva Conventions. First established in 1864, and revised and updated in 1949 under the auspices of the ICRC, these conventions regulate the conduct of armed conflict and protect its victims. The formerly colonised states of the Third World, which had not been involved in drawing them up, were a driving force behind the call for a revision of IHL that was taken up by the ICRC and various UN bodies. The questions of whether so-called freedom fighters should be legally protected, and if, and in what form, they should be able to participate in the development of international law were some of the most controversial issues. This debate primarily pitted Third World governments against the leaders of the Western bloc. ${ }^{85}$ The Swiss government played a major role in this regard. In early 1974, as depository state of the Geneva Conventions, it convened a diplomatic conference to reaffirm and develop IHL applicable in armed conflicts. The demand that liberation movements be invited to participate in this conference, voiced by African leaders and fiercely opposed by the UK and the US, therefore placed Bern in a difficult position.

The story of the Swiss government's relations with the ICRC and the latter's role in Swiss foreign policy is a long and complex one. ${ }^{86}$ The ICRC was founded

85 Some indications about these dynamics can be found in David P. Forsythe, The Humanitarians. The International Committee of the Red Cross, Cambridge: Cambridge University Press, 2005, pp. 261-263.

86 A complete account of the relations between the Swiss government and the ICRC still needs to be written, although several authors have treated this question. See notably Baudendistel, Between Bombs and Good Intentions, pp. 7-49; Thomas Brückner, Hilfe schenken. Die Beziehung zwischen dem IKRK und der Schweiz, 1919-1939, Zürich: NZZ Libro, 2017; François Bugnion, Le Comité international de la Croix-Rouge et la protection des victimes de la guerre, 2nd ed., Geneva: Comité international de la Croix-Rouge, 200o, pp. 1156-1175; Forsythe, The Humanitarians, pp. 183-92; Hans Peter Gasser, "The International Committee of the Red Cross and its Development since 1945", in Gabriel, Fischer, Swiss Foreign Policy, pp. 105-126; Hans Haug, "Die Schweiz, die Rotkreuz- und Rothalbmondbewegung und das Internationale Komitee vom Roten Kreuz", in Alois Riklin, Hans Haug, Raymond Probst (eds.) Neues Handbuch der schweizerischen Aussenpolitik, Bern: Haupt, 1992, pp. 677-691; Isabelle Vonèche Cardia, Neutralité et engagement. Les relations entre le Comité 
in 1863 in Geneva and is, on a legal level, a private association incorporated under Swiss law. There are, however, strong ties between the ICRC and its host country, which are most visibly represented by the organisation's emblem, which is an inversion of Switzerland's national flag. Both the ICRC and the Swiss government are neutral, but their conceptions of neutrality differ. While Switzerland's neutrality is anchored in international law, that of the ICRC is based on its standing practice and was confirmed by the International Conferences of the Red Cross of 1965 and 1986. The organisation generally abstains from participating in political controversies and in principle treats all belligerents equally in order to aid all victims of conflict. Its freedom of action is more restricted than that of the Swiss government. ${ }^{87}$ The two bodies mutually reinforce each other's neutral standing; while the ICRC's seat in a neutral state is deemed to guarantee its impartial humanitarian action, the Swiss authorities consider the ICRC a pillar of Switzerland's humanitarian image that improves the international reputation of its neutrality, and a foreign policy asset. Following criticism of the ICRC's silence on the holocaust, which some scholars have attributed to Swiss government influence, ${ }^{88}$ efforts were made to increase the organisation's independence. In 1993, the ICRC and the Swiss government signed a headquarters agreement, making the ICRC's premises off-limits to Swiss authorities. Although the members of the organisation's governing board are still exclusively Swiss, the professional staff has been internationalised since the early 1990s. In the late 1960s, however, many former Swiss diplomats and politicians sat on the Committee. Finally, Switzerland is also the ICRC's main financial contributor. In 1975, the Swiss government covered more than one third of the cost of the Geneva headquarters and slightly less than one ninth of field operation expenses. ${ }^{89}$ Thanks to these close links between the Swiss government and the humanitarian organisation, which frequently blurred the distinctions between them in the eyes of international observers, the former was particularly interested in the revision of humanitarian law.

In the late 196os, the broad question of human rights during armed conflicts and the revision of the Geneva Conventions and the 1907 Hague Conventions on the laws of war was on the agenda of the UN. Resolution XxIII of the Tehran

international de la Croix-Rouge (CICR) et le Gouvernement suisse 1938-1945, Lausanne: SHSR, 2012; Albert Wirz, "Die humanitäre Schweiz im Spannungsfeld zwischen Philanthropie und Kolonialismus: Gustave Moynier, Afrika und das IKRK", Traverse 5 (1998), pp. 95-110.

87 Bugnion, Le Comité international de la Croix-Rouge, pp. 1159-63.

88 An overview of this debate can be found in Vonèche Cardia, Neutralité et engagement, pp. 24-26.

89 Wirz, "Die humanitäre Schweiz", p. 100. 
International Conference on Human Rights, held in April and May 1968, invited the UN Secretary General to study means to ensure the better application of existing humanitarian law and the need for additional conventions to better protect civilians and combatants in armed conflicts. His report was later analysed by several UN commissions and discussed at the UNGA..$^{90}$ The ICRC's mandate to address these problems was a result of Swiss and Western lobbying. For the Swiss government, the reaffirmation and development of IHL was an opportunity to play a role in international humanitarian diplomacy, but only if it took place under the auspices of the ICRC. As a non-member of the UN, Switzerland was excluded from negotiations at the UNGA. Prior to the Tehran conference, FPD leaders were concerned about the "risk of seeing the United Nations, as a result of their role in the protection of human rights, gradually assume competence in areas which have always been the responsibility of the ICRC" ${ }^{91}$ The Swiss authorities feared that their humanitarian image would suffer if the ICRC's status were to diminish. Discussions between the two bodies in mid-1969 show clearly that the initiative to press for the ICRC to take on the revision of IHL came from Bern. ICRC delegates underlined repeatedly that their main goal was the revision of humanitarian law, even if this was to take place within UN frameworks. However, Ernesto Thalmann, the head of the DIO, argued that the revision could only succeed if directed by the ICRC. Discussions at the UN, he feared, would be politicised, especially with regard to the status of members of liberation movements. This would lead to the distortion of international law. For this reason, he was even hesitant to include independent Third World governments too heavily in the revision of humanitarian law. ${ }^{92}$ At the 21st International Conference of the Red Cross, in Istanbul in Sep-

$90 \quad$ No author, "Brief for the United Kingdom Delegation to the Twenty-Fifth Session of the United Nations General Assembly. Item 47: Respect for Human Rights in Armed Conflicts", no date, p. 1, attached to the note from the FCO to the UK Steering Committee on International Organisations, 16.11.1970, TNA FCO 61/68o.

$91 \quad$ FPD, proposal to the Federal Council, "Conférence internationale des droits de l'homme, Téhéran, 22 avril - 13 mai 1968, o1.03.1968”, p. 4, attached to the decree of the Federal Council, "Conférence internationale des droits de l'homme, Téhéran, 22 avril - 13 mai 1968", 20.03.1968, dodis.ch/34271.

92 Jean Pictet, Director General of the ICRC, memorandum of conversation with Ernesto Thalmann, head of the DIO, and Denise Werner, chief of the Dio's International Aid Organisations Section, on 5 August 1969, "Restauration du droit de la guerre", no date, confidential, especially p. 3, ICRC archives, Geneva, Switzerland (ACICR) B AG 059-073; see also Jean Pictet, memorandum of conversation with Ernesto Thalmann, Friedrich Traugott Wahlen, Federal Councillor and head of the F PD, Pierre Micheli, Secretary General of the FPD and head of the DPA, Jean Cuendet, DPIL, and Denise Werner on 19 August 1969, no date, confidential, ibid. 
tember 1969, the head of the Swiss delegation therefore proposed a resolution that mandated the ICRC to continue the examination of the problem together with governmental experts, which was unanimously adopted. ${ }^{93}$

Many Western governments shared the wish to have the ICRC deal with the revision of IHL. They hoped that this would depoliticise the issue and that they would have a greater say than if the matter were dealt with by the UNGA, where the Afro-Asian majority could impose its views. The British government was particularly active in this regard. Members of the Foreign and Commonwealth Office (FCO), realising in mid-1970 that the movement to revise international law was too strong to be ignored, decided instead to take an active role in influencing the development of humanitarian law. In a meeting with Claude Pilloud of the ICRC Directorate in July 1970, they encouraged the Geneva organisation to draft new IHL instruments. ${ }^{94}$ They also undertook considerable efforts to ensure that the controversial issue of liberation movements be kept out of UN debates as much as possible and lobbied their NATO allies and other friendly governments to support the ICRC initiative. ${ }^{95}$ The US State Department was more restrained and hesitated to support a revision of international law in armed conflict as long as American soldiers were engaged in Vietnam. ${ }^{96}$

This Swiss and Western lobbying proved fruitful. The ICRC, which had received an official mandate from the Istanbul Red Cross conference in late 1969, developed drafts for additional humanitarian legislation. These were subsequently discussed during conferences of the National Red Cross and Crescent Societies and at two meetings of governmental experts. At the last session, in June 1972, 400 specialists from 77 states reached broad agreement on the texts for two additional protocols to the Geneva Conventions. Therefore,

93 See Pierre Graber, Federal Councillor and head of the FPD, proposal to the Federal Council, "Conférence diplomatique sur le droit humanitaire", 20.08.1972, p. 1, attached to the decree of the Federal Council, "Conférence diplomatique sur le droit humanitaire", 18.09.1972, SFA E2OO3A\#1984/84\#1390*.

94 Claude Pilloud, member of the ICRC Directorate, "Entretien au Foreign Office à Londres", 28.07.1970, ACICR B AG 059-120; no author, "Record of a meeting held at the Foreign and Commonwealth Office on Tuesday, 28 July, 1970, at 2.00 p.m. [with Claude Pilloud]", 12.08.1970, TNA FCO 61/678. See also note from Merrick S. Baker-Bates, FCO, to Hilary W. King, United Nations (Economic and Social) Department of the FCO, "Human Rights in Armed Conflict", 26.06.1970, TNA FCO 61/679.

95 Letter from Hilary W. King to Tessa A. H. Solesby, UK Mission in New York, "Respect for Human Rights in Armed Conflict", 21.08.1970, TNA FCO 61/678.

96 Letter from Tessa A. H. Solesby to John A. Wilberforce, United Nations (Economic and Social) Department of the FCO, "Human Rights in Armed Conflict", 16.og.1970, p. 1, TNA FCO $61 / 678$. 
the Federal Council agreed in September of that year to convene a diplomatic conference in Geneva in early 1974, which would discuss and eventually adopt the two additional protocols. ${ }^{97}$

The hope that moving the revision of IHL from New York to Geneva would depoliticise the debate proved to be in vain. African liberation movements wanted wars of national liberation to be recognised as international conflicts. On the one hand, this would ensure a better protection of their fighters when taken prisoner. On the other hand, it would elevate them to belligerents on a par with the colonial authorities and thereby enhance their legitimacy and that of their cause. During a discussion with ICRC representatives in August 1970 in Algiers, delegates of liberation movements expressed their wish to collaborate with the ICRC on the revision of IHL, as well as in the conflict zones. They noted indiscriminate bombings and the use of prohibited chemical weapons by the Portuguese army and contrasted it to their own adherence to humanitarian principles. FRELIMo delegate José Oscar Monteiro, in particular, highlighted his movement's humanitarian policy and willingness to free Portuguese prisoners of war. ${ }^{98}$ Independent African governments supported the liberation movements' concerns. In June 1971, The OAU's Council of Ministers called for a worldwide campaign "to apply to freedom fighters the relevant articles of [the] Geneva Convention of 1949 on the treatment of prisoners of war and to ensure participation of liberation movements in the drafting and application of international humanitarian law applicable to the so-called internal conflicts". 99

For the Swiss government, the difficulties began in early 1973, when the Norwegian government demanded that African liberation movements be admitted to the diplomatic conference in Geneva. Since the early 1970s, NATO member Norway had spoken out strongly in favour of the application of the Geneva Conventions to wars of national liberation. British and US delegates in particular resented this. Oslo was subsequently excluded from meetings of

97 Decree of the Federal Council, "Conférence diplomatique sur le droit humanitaire", 18.09.1972, SFA E2003A\#1984/84\#1390*; see also Pierre Graber, proposal to the Federal Council, "Conférence diplomatique sur le droit humanitaire", 20.08.1972, attached to this document.

98 Michel Veuthey, ICRC Legal Department, memorandum, "Consultations sur le droit humanitaire international applicable dans les conflits non internationaux et la guérilla. Entretiens à Alger, dans les locaux du Croissant-rouge algérien, les 5, 6 et 7 août 1970", pp. 3-4, 13.08.1970, ACICR B AG 059-203.01.

99 Resolution CM/Res. 242 (XVII) of the OAU Council of Ministers' $17^{\text {th }}$ Ordinary Session from 15 to 19 June 1971, "Resolution on Apartheid and Racial Discrimination", https:// au.int/sites/default/files/decisions/9586-council_en_15_19_june_1971_council_ministers_ seventeenth_ordinary_session.pdf (13 January 2021). 
a Western working group that first met in London in September 1972 to coordinate a common approach to the Geneva conference. In April 1973, the Norwegian government hosted the UN-OAU International Conference of Experts for the Support of Victims of Colonialism and Apartheid in Southern Africa. ${ }^{100}$ On his return from this conference, an ICRC representative informed the FPD in confidence that the Norwegian government planned to request the invitation of African liberation movements to the diplomatic conference. François Pictet, deputy chief of the DiO, suggested that Oslo be discreetly told that Switzerland did not approve of this demand. Thereby, he hoped to avoid having to publicly refuse an invitation. ${ }^{101}$ The outright rejection of the liberation movements' participation illustrates the FPD leaders' distrust of these non-state actors. Unlike the ICRC, which had consulted African nationalists during the elaboration of the additional protocols in Algiers in 1970 and in Algiers and Cairo in 1972-1973, the FPD did not even discuss the possibility of inviting them to Geneva. ${ }^{102}$ Swiss foreign policymakers underestimated the strength of the liberation movements' cause. Unimpressed by the Swiss protests, in May 1973 the Norwegian embassy in Bern formally invited the Federal Council to inform the parties to the Geneva Conventions of the liberation movements' wish to participate in the humanitarian law conference. ${ }^{103}$ In June 1973, the OAU added weight to this demand. Following a resolution by its Council of Ministers, the General Secretariat sent a note to the Swiss embassy in Ethiopia, asking the

100 See notably Harold Beeley, UK Mission in Geneva, to Sir Vincent Evans, Legal Advisor at the FCO, "ICRC Conference on Humanitarian Law", o1.o6.1971, p. 1, TNA FCO 61/810; letter from I. K. C. Ellison, UN Department, to C. J. Makins, UK embassy in the US, "ICRC Conference on Humanitarian Law in Armed Conflict”, 16.o6.1972, pp. 1-2, TNA FCO 61/957; telegram from Sir Alec Douglas-Home, Foreign Secretary, to UK embassies in Canada, France, FRG, US, Denmark, Belgium, Australia, The Netherlands, Italy, Turkey, New Zealand, and to the mission in Geneva, "Western Working Group Consultations on Humanitarian Law in Armed Conflicts", 11.08.1972, TNA FCO 61/957. On the 1974 Oslo conference, see Tore Linné Eriksen, "The Origins of a Special Relationship: Norway and Southern Africa 1960-1975", in Eriksen, Norway and National Liberation in Southern Africa, pp. 9-89, pp. $5^{6-73}$.

Note from François Pictet, deputy chief of the DIo, to the chief of the DIo, "Conférence diplomatique sur le droit humanitaire. Mouvements de libération nationale”, 25.04.1973, p. 2, SFA E2OO3A\#1988/15\#1140*.

Michel Veuthey, memorandum, "Consultations sur le droit humanitaire international applicable dans les conflits non internationaux et la guérilla. Entretiens à Alger, dans les locaux du Croissant-rouge algérien, les 5, 6 et 7 août 1970", 13.08.1970, ACICR B AG 059203.01; Veuthey, memorandum, "Mission en Algérie du 5 au 10 octobre 1972", 18.10.1972, ACICR B AG 059-396.o5; note no 1936 from Marcel A. Boisard, ICRC office in Egypt, to Jean-Pierre Hocké, Delegate General, "Entretiens avec les mouvements de résistance", 24.02.1973, ACICR B AG 059-396.05.

Royal Norwegian Embassy in Bern, aide-mémoire, 21.05.1973, SFA E2003A\#1988/15\#1140*. 
Swiss government to take all necessary steps to "ensure the effective participation of the liberation movements recognised by the OAU at this diplomatic conference". 104

Although the conference was competent to decide on admissions by plenary vote, the DIO and the ICRC agreed that a solution ought to be found discreetly in advance to avoid political debates. Independently, they concluded that the OAU, which had observer status, should represent the liberation movements. On 22 June 1973, during a regular meeting of ICRC delegates, FPD officials, and the Secretary General of the conference, Swiss ambassador Jean Humbert, it was agreed that broad participation in the Geneva conference was desirable, so that all belligerents would feel bound by the resulting protocols. However, concessions to the liberation movements must not result in the withdrawal of the Portuguese and South African delegations. The DIo therefore suggested trying what was later called the 'Swiss compromise' - the representation of liberation movements by the OAU - on the US, British, and French governments that were hostile to the presence of the liberation movements. ${ }^{105}$ Trying to garner support for this compromise solution, the Swiss government was caught between fronts.

The British authorities, which closely followed the organisation of the diplomatic conference and continually lobbied the Swiss government and the ICRC, would have preferred the liberation movements to be absent from Geneva and were firmly opposed to granting them observer status. British interest in this area is explained by the concern that the additional protocols would be applied to the conflict between the British authorities and the Irish Republican Army (IRA) that fought for the independence of Northern Ireland. Nevertheless, the FCO agreed that the Swiss compromise was the best that could be expected. ${ }^{106}$

104 Letter from the OAU Secretariat to the Swiss embassy in Ethiopia, 13.06.1973, attached to the letter from Hans Schärer, chargé d'affaires a.i. of the Swiss embassy in Ethiopia, to the DIO, "'Conférence diplomatique sur le droit humanitaire'. Teilnahme afrikanischer Befreiungsbewegungen", 19.06.1973, SFA E2003A\#1988/15\#1140*; see also resolution CM/ Res. 307 (xx) of the OAU Council of Ministers' 21st Ordinary Session from 17 to 24 May 1973, "Resolution sur la conférence diplomatique sur le droit humanitaire", attached.

105 Note from François Pictet to the chief of the DiO, "Participation des mouvements de libération nationale à la Conférence diplomatique sur le droit humanitaire", 26.o6.1973, SFA E2003A\#1988/15\#1140*; see also the note from François Pictet to the chief of the DIO, "Participation des mouvements de libération nationale à la Conférence diplomatique sur le droit humanitaire", 19.06.1973, ibid; A. Martin, ICRC, memorandum of conversation with representatives of the FPD, "Conférence diplomatique de 1974", 25.06.1973, pp. 1-2, ACICR B AG 152-045.

106 Note from R. J. A. Martin, UN Department, FCo, to R. C. Cox, Northern Ireland Office, "Draft protocol to article 3 of the Geneva Conventions and Northern Ireland, 21.05.1973, TNA FCO 61/109o; letter from M. A. Arthur, UN Department, FCO, to Gillian G. Brown, 
While this solution was just about acceptable to most Western governments, OAU representatives told Jean Humbert during a meeting in Addis Ababa in October 1973 that the liberation movements would find it difficult to accept being represented by the OAU, considering that they had already achieved observer status at the Fourth Committee of the UNGA and at the International Labour Organization (ILO).107 In a press communiqué, the OAU insisted on the necessity for "the independent states of Africa to review the agreements concluded on their behalf by their former colonial administrators." The invitation of the liberation movements would avoid the need for further revision of IHL once colonialism was truly over. ${ }^{108}$ Because of the liberation movements' resistance to the Swiss compromise, the DIO started to modify its proposal, granting them extensive rights if they would accept being part of the OAU delegation, including the right to be present at all times and a right to speak.109

In December 1973, the US authorities, which had been content until the twenty-eighth session of the UNGA to let the British take the lead in Western lobbying efforts, took a more active interest in the Geneva conference. George W. Aldrich, the deputy legal advisor of the State Department and intended head of the US delegation to the Geneva conference, was concerned about what he considered to be the resigned attitude of the Western delegations regarding the presence of the liberation movements. He informed the Swiss embassy in Washington that the US government might reconsider its presence if the liberation movements were to be invited in their own name and urged the Swiss to find a solution before the beginning of the conference. ${ }^{110}$ The new US attention to the issue was linked to the ratification by the Provisional Revolutionary Government of South Vietnam (PRG) of the Geneva Conventions shortly before the conference; this step allowed the PRG to demand an invitation. ${ }^{111}$ In January

UK Embassy in Switzerland, "Diplomatic Conference on Humanitarian Law in Armed Conflict", 20.07.1973, p. 1, ibid.; Gaspard Bodmer, memorandum, "Conférence sur le droit humanitaire; participation des mouvements de libération nationale africains", 25.07.1973, p. 1, SFA E2OO3A\#1988/15\#1140*.

107 Report no 6 from Ambassador Jean Humbert, General Commissioner for the Diplomatic Conference on International Humanitarian Law, to the Dio, "Participation des mouvements africains de libération nationale à la Conférence sur le droit humanitaire. Voyage du Commissaire général à Addis Abeba", 23.10.1973, pp. 4-5, SFA E2003A\#1988/15\#1140*.

108 OAU press communiqué, 13.10.1973, SFA E2003A\#1988/15\#1140*.

109 François Pictet, memorandum, "Participation des mouvements de libération nationale à la Conférence diplomatique”, 11.12.1973, pp. 1, 4-5, SFA E2003A\#1988/15\#1140*.

110 Telegram no 633 from Felix Schnyder, Swiss ambassador in the US, to the FPD, 12.12.1973, p. 1, SFA E2OO3A\#1988/15\#1140*.

111 No author, memorandum, "Humanitarian Law in Armed Conflict. US/UK Bilateral Consultations, 30 January 1974, Foreign and Commonwealth Office”, no date, p. 2, TNA FCO 61/1238. 
1974, the US State Department instructed its representations in selected African states to support the Swiss compromise. ${ }^{12}$ Fearing that these US lobbying attempts might be counterproductive, François Pictet of the DIO expressed his hope that they "were made with great tact to avoid creating the impression that the Swiss proposal was inspired by America."113 Indeed, the deputy Secretary General of the OAU told Ambassador Heinz Langenbacher that the US initiative had rendered some OAU members more distrustful of the Swiss compromise. ${ }^{114}$

In January 1974, the OAU organised an IHL seminar for African liberation movements in Dar es Salaam. At this event, Jean Humbert was unable to convince the liberation movements to accept the Swiss compromise. The African nationalists suggested instead that the Swiss government officially invite the liberation movements that were recognised by the OAU and that the conference should then decide on the terms of their presence. ${ }^{115}$ Since they considered that the extension of official invitations exceeded their authority as convening power, the Swiss authorities rejected this counterproposal. They agreed, however, to issue visas to the nationalist representatives so that they could be present in Geneva. ${ }^{116}$ On this point, the head of the Dio, René Keller, overruled his deputy, who preferred to use the visas as leverage and only grant them if the diplomatic conference decided to invite the liberation movements. Keller feared that many states would accuse Switzerland of "playing into the hands of colonialism and imperialism" if the visas were not issued and thus made a concession to the political power of Third World countries. ${ }^{117}$ As a

112 Telegram from Kenneth Rush, Deputy Secretary of State, to the US embassies in the Ivory Coast, Ghana, Ethiopia, Nigeria, Liberia, Kenya, 15.01.1974, NARA, RG 59, Access to Archival Databases (AAD), https://aad.archives.gov/aad/index.jsp (13 January 2021), Central Forł eign Policy Files (CFPF), Electronic Telegrams 1974, 1974STATEoo8939.

113 Telegram no 11 from François Pictet to the Swiss embassy in the US, 15.01.1974, SFA E2003A\#1988/15\#1140*.

114 Letter from Heinz Langenbacher to the DIo, "Rotkreuzkonferenz: Befreiungsbewegungen”, 22.01.1974, confidential, p. 2, SFA E2003A\#1988/15\#1140*.

115 OAU Liberation Committee, minutes, "Compte-rendu du séminaire de l'OUA sur le droit humanitaire. Tenue à Dar-es-Salaam du 21 au 25 janvier 1974", no date, SFA E2003A\#1988/15\#1140*. See also report no 9 from Jean Humbert to the DIO, "Voyage à Dar es-Salaam - Séminaire pour les mouvements africains de libération nationale", 28.01.1974, SFA E2003A\#1988/15\#573*; Michel Veuthey, memorandum, "Séminaire organisé par l'OUA pour les mouvements de libération africaine en vue de la Conférence diplomatique sur le droit humanitaire - Dar es-Salaam, 21 - 25 janvier 1974", o8.02.1974, ACICR B AG 152-046.o3.

116 Telegram no 8 from Ernesto Thalmann, Secretary General of the FPD, to the Swiss embassy in Tanzania, 24.01.1974, SFA E2003A\#1988/15\#1140*.

117 Note from René Keller to the Secretary General of the FPD, "Participation des mouvements de libération nationale à la Conférence diplomatique”, 23.01.1974, urgent, p. 2, SFA E2003A\#1988/15\#1140*. 
consequence of the African liberation movements' decision to reject the Swiss compromise, the Arab League demanded that the Palestine Liberation Organization (PLO) also be invited in its own name. Although the PLO had already agreed that its representative be included in the delegation of the Arab League, PLO representatives expressed their solidarity with the OAU decision in Dar es Salaam and went back on the earlier agreement. ${ }^{118}$

The memorandum of a meeting held between DIO members and two ICRC delegates less than two weeks before the start of the conference reveals the two bodies' different attitudes towards the invitation issue. The former insisted on the importance of the participation of liberation movements and provisional governments like the PRG in the conference and urged Bern to find some kind of solution before negotiations began. François Pictet of the DIO admitted that the FPD had long underestimated the determination of the liberation movements' supporters and was only now addressing the issue properly. Nevertheless, he insisted that his division did not have the time and manpower necessary to enter into negotiations with African delegations. After this meeting, JeanPierre Hocké, Director of the ICRC's Operations Department, expressed his satisfaction that the Swiss government was now more open to the liberation movements: "the FPD realises that it will be very difficult, if not impossible, to take refuge behind the rather legal position that it has adopted so far".119

All efforts to arrange a compromise solution for the participation of African liberation movements before the start of the conference failed. Negotiations in committees and regional groups continued in Geneva. The status of these movements, as well as the PRG and the PAIGC government in Guinea-Bissau, which had unilaterally declared its independence from Portugal in September 1973 and deposited instruments of accession to the Geneva Conventions on 21 February 1974, dominated the first part of the conference. ${ }^{120}$ Finally, a consensus was reached on admitting Guinea-Bissau to the conference with full rights and the liberation movements as observers with all rights except the right to vote. ${ }^{21}$ The US delegation accepted this compromise without a vote in order to separate the status of the African movements from that of the PRG, whose

118 Telegram no 39 from Yves André Berthoud, Swiss embassy in Egypt, to the FPD, 14.02.1974, p. 1, SFA E2OO3A\#1988/15\#1140*.

119 Jean-Pierre Hocké, memorandum, "Participation des mouvements africains, du GRP et du GRUNC à la Conférence diplomatique”, p. 2, 12.02.1974, ACICR B AG 059-397.02. Telegram from Francis Lykins Dale, US Mission in Geneva, to the Secretary of State, "Laws of War Conference - Current Status", p. 2, NARA, RG 59, AAD, CFPF, Electronic Telegrams 1974, 1974GENEVAo1188.

121 Second circular letter from René Keller to all Swiss embassies, "Conférence diplomatique sur le droit humanitaire”, 04.03.1974, p. 1, SFA E2003A\#1988/15\#1140*. 
invitation to the conference was defeated in an extremely tight vote. ${ }^{122}$ This decision disappointed the Executive Council of the ICRC, whose members had wanted participation in the conference to be as universal as possible. ${ }^{123}$

The admission of African liberation movements to the 1974 ICRC Diplomatic Conference on the Reaffirmation and Development of IHL Applicable in Armed Conflicts represented an important diplomatic victory for themselves and their supporters. FRELIMO heralded it as "a great victory for the Mozambican people and for all other peoples fighting for their freedom." In the English-language periodical Mozambique Revolution, edited by its Department of Information and aimed at an international audience, FRELIMO demanded that Portugal apply and respect the Geneva Conventions, concluding that, "the best and most effective way of putting an end to the suffering inflicted on our people by the war is to eliminate the very causes of war as soon as possible, in other words, to put an end to Portuguese colonialism and imperialism."124 Many Western delegations were frustrated by the lack of substantive results and the omnipresence of what they perceived as tiresome political debates during the conference. According to Jean Humbert, the lack of contact between the Non-Aligned bloc and those Western delegations that defended a traditional interpretation of $\mathrm{IHL}$, and the latter's obstinacy and refusal to propose compromise-based solutions, allowed the former to benefit from their numerical weight. Thus, they managed to push through an amendment to elevate liberation wars to the level of international conflicts, which significantly improved the status of liberation movements. ${ }^{125}$ The conference report of the British

122 George W. Aldrich, chairman of the US delegation, "Classified Report of the United States Delegation to the Diplomatic Conference on the Reaffirmation and Development of International Humanitarian Law Applicable in Armed Conflicts", 10.06.1974, Foreign Relations of the United States (FRUS) Online, https://history.state.gov/historicaldocuments (13 January 2021), 1969-1976, vol. E-3, doc. 235. The admission of the PRG was defeated with 38 against 37 votes, with 33 abstentions: no author, "Vote sur l'admission ou la non admission du Gouvernement révolutionnaire provisoire du Vietnam du Sud", 28.02.1974, attached to the second circular letter from René Keller to all Swiss embassies, "Conférence diplomatique sur le droit humanitaire”, 04.03.1974, p. 1, SFA E2003A\#1988/15\#1140*.

123 J. Ott, ICRC, memorandum of conversation between Roger Gallopin, President of the ICRC's Executive Council, and ambassador Nguyen Van Luu, head of the Department of International Organisations and International Law of the Ministry of Foreign Affairs of the Democratic Republic of Vietnam and deputy head of delegation, 12.02.1974, p. 1, ACICR B AG 152-046.02.

124 No author, "FRELIMO in world events", Mozambique Revolution $5^{8}$ (January-March 1974), pp. 10-11, p. 11.

125 Report no 11 from Jean Humbert to the Dio, "Considérations de caractère général sur les travaux de la Conférence qui a eu lieu du 20 février au 29 mars 1974”, 10.04.1974, p. 5, SFA E2003A\#1988/15\#1140*. 
delegation, written in June 1974, was unequivocal about the results of the conference: "To the extent that there were any, they were lamentable." According to the delegation, the lack of progress was due to the political agenda of Third World countries and the tug of war between the Communist bloc and the US regarding the PRG - and the Swiss organisers' lack of leadership. ${ }^{126}$ George W. Aldrich, the leader of the US delegation, heartily concurred with this assessment and explained it by the "unfamiliarity of the Swiss Government with the rough and tumble of United Nations politics."127

As political debates stalled the work of the 1974 conference, three more diplomatic conferences and numerous formal and informal meetings took place until the two additional protocols aimed at improving the protection of the civilian population and codifying the norms applicable to non-international armed conflicts were finally adopted in $1977 .{ }^{128}$ Even then, many states either did not sign or never ratified Protocol I that dealt with international war, notably the US and the UssR. The UK and France only did so after the end of the Cold War. ${ }^{129}$

For the Swiss government, the Geneva conference of February and March 1974 was an opportunity to secure the ICRC's and its own influence in the debate on the revision of IHL in armed conflicts, play a role on the international stage, and strengthen its image as a neutral, humanitarian actor. However, due to the conference's strong polarisation along North-South lines, it was only partly successful. The issue of the African liberation movements' admission highlights Bern's disregard for these actors and their goals. The DiO was convinced that African nationalists had no legal claim to representation, and underestimated both their determination to be present in their own name and the support they could rely on from the Afro-Asian bloc and some Western states, notably NATO member Norway. Given the Swiss authorities' interpretation of their position as convenors of the Geneva conference as a passive role, they refrained from taking initiatives and making more substantial concessions

126 Report of the British delegation, "Diplomatic Conference on Humanitarian Law in Armed Conflict. Geneva 20 February - 29 March 1974: First Session”, 17.06.1974, citation p. 1, TNA FCO 61/1233.

127 George W. Aldrich, "Classified Report of the United States Delegation to the Diplomatic Conference on the Reaffirmation and Development of International Humanitarian Law Applicable in Armed Conflicts", 10.o6.1974, FRUS Online, 1969-1976, vol. E-3, doc. 235. Yves Sandoz, "La Suisse et le droit international humanitaire, en particulier les conventions de Genève pour la protection des victimes des conflits armés", in Riklin, Haug, Probst, Neues Handbuch der schweizerischen Aussenpolitik, pp. 247-263, p. $25^{2}$.

129 Amanda Alexander, "A Short History of International Humanitarian Law", The European Journal of International Law 26:1 (2015), pp. 109-138, p. 126. 
that might have allowed the issue to be resolved before the beginning of the conference. At the same time, their leeway was limited, as although the British and US administrations repeatedly pressured the FPD to achieve a solution in advance, it is doubtful that they would have agreed to grant the liberation movements far-reaching privileges.

In this context, the Swiss government, as convenor of the conference, did not make a good impression. While Western delegations criticised its passivity and lack of clear direction, representatives from the Third World expressed their incomprehension that the liberation movements had not been invited. In a conversation with members of the DIO during the conference, FRELIMO delegate José Oscar Monteiro, the spokesman for the liberation movements in Geneva, criticised the Swiss government for its one-sided stance during the independence wars in Southern Africa. Neutrality, according to Monteiro, was no excuse for not taking a stand for the liberation movements, especially as neutral Sweden and NATO-member Norway had already done just that. ${ }^{130}$ Uttered barely a month before the Carnation Revolution, these words were indicative of the gulf between the Swiss authorities and the liberation movements, which would complicate relations after the independence of Mozambique and Angola.

Starting in 1967, Afro-Asian leaders criticised Switzerland's interpretation of a neutral foreign policy as one that refused to acknowledge the political consequences of economic activities at the $\mathrm{UN}$, the OAU, and international organisations in Geneva. The Swedish counterexample strengthened this criticism. However, in the eyes of the major Western powers, whose political line in Southern Africa Swiss foreign policymakers followed and towards whom their neutrality policy had traditionally been oriented, it was clear who the 'good neutrals' were. Western observers underlined the Swiss government's 'sensible' approach to Third World issues - an approach that did not undermine their position as Sweden and Norway did. They therefore welcomed its more active foreign policy, as the British ambassador in Bern eloquently put it in mid-1973:

It seems to me that we can only gain if Switzerland does take a more relaxed view of its neutrality, if it does, for example, finally take the plunge and join the UN. [...] [T]here is no doubt where Switzerland's sympathies lie (for what it is worth, within 10 minutes of my meeting M. Celio, the Minister of Finance, he remarked [...] that no former British

130 Letter from François Pictet to the Swiss embassies in Ethiopia and Tanzania and the Office of the Permanent Observer of Switzerland to the UN, "Possibilité d'une aide suisse en Afrique australe”, 29.04.1974, SFA E2005A\#1985/101\#547*. 
colony was now better off than it had been under British rule). Switzerland may be small and often narrow in its outlook, but its assets as a stable, democratic and wealthy State, with solid views on world affairs, more solid one might say than any of the other European neutrals, are not to be underrated. ${ }^{131}$

131 Diplomatic report no 252/73 from John Richard Wraight, British ambassador in Switzerland, to the British Secretary of State, "First Impressions of Switzerland", 01.05.1973, p. 6, TNA FCO 33/2279. 